\title{
MINI PLANT SISTEM PENGENDALI BERAT LIMESTONE PADA PLTU TANJUNG JATI B UNIT \#3\&4 BERBASIS PLC DANARDUINO MEGA 2560
}

\author{
Surya N Santika, Nachrowie, Dwi Arman Prasetya, Basitha F Hidayatulail \\ Jurusan Teknik Elektronika UNMER Malang \\ Email : Suryansant23@gmail.com
}

\begin{abstract}
Abstrak
PLTU Tanjung Jati B Unit \#3\&4 merupakan unit pembangkit yang menghasilkan produksi listrik sebesar 660 MW setiap hari nya. Bahan bakar yang digunakan batu bara yang menghasilkan produk utama yaitu Flue Gas dan Ash yang mempunyai limbah industri B3 yang penanganannya membutuhkan metode khusus menggunakan FGD (Flue Gas Desulfurization) yaitu alat yang berguna untuk mereduksi Sulfur Dioksida (SO2) dari Flue Gas hasil pembakaran PLTU. Pada proses FGD, batu kapur (limestone) digunakan sebagai bahan injeksi FGD, berfungsi mengikat SOx menjadi gypsum sehingga kadar emisi SOx dari hasil pembakaran batu bara aman bagi lingkungan. Perancangan Mini Plant Sistem Pengendali Berat Limestone pada FGD berbasis PLC dan Arduino Mega 2560 sangat diperlukan untuk menjaga perhitungan stock Limestone yang akurat secara otomatis agar emisi SOx dapat tereduksi dengan baik.
\end{abstract}

Kata Kunci: FGD,Llimestone,PLC, Arduino Mega

\section{Pendahuluan}

Penggunaan batubara sebagai bahan bakar pada PLTU menimbulkan masalah lingkungan yang serius.Sehingga mendorong pemerintah untuk mengembangkan teknologi untuk mengatasi masalah ini.Flue Gas Desulfurization (FGD) merupakan teknologi baru yang dapat mengurangi emisi $\mathrm{SO} 2$ sehingga lingkungan tetap terjaga.Pada prosesnya FGD menggunakan limestone (batu kapur) untuk dapat mengikat SOX dan menghasilkan gypsum[1][2]. Kurang valid nya pembacaan data berat dari limestone menyebabkan error yang besar dan maintenance harus sering melakukan kalibrasi sehingga dibutuhkan sistem kontrol otomatis yang dapat mengontrol dan membaca berat limestone per satuan waktu yang digunakan pada proses FGD secara real oleh operator[3].

PLC (Programmable Logic Controller) dapat dibayangkan seperti sebuah personal komputer konvensional (konfigurasi internal pada PLC mirip sekali dengan konfigurasi internal pada personal komputer)[4][5]. Akan tetapi dalam hal ini PLC dirancang khusus untuk tujuan kontrol dan otomasi. Bidang industri biasa menggunakan proses penghitungan dan konveyor barang untuk mempermudah proses pemasukan bahan bakar padat (batubara) ke dalam tungku atau dengan istilah limestone weigh feeder. Proses penghitungan jumlah berat bahan bakar padat ditimbang jumlahnya persatuan jam, dengan memanfaatkan fungsi pencacah (counter), limit swich, sensor berat dan pewaktu (timer) yang dimiliki oleh PLC (Programmable Logic Controller)[6][7].

Dalam penelitian ini bertujuan merancang Mini Plant Sistem Pengendali Limestone pada PLTU Tanjung Jati B Unit \#3 dan 4 lebih sederhana daripada sistem pengendali weight feeder dengan menggunakan PID dan Fuzzy dimana proses penghitungan berat limestone menggunakan PLC dan Arduino Mega 2560. Arduino Mega 2560 dipilih karena bahasa pemrograman yang lebih sederhana dibanding sistem kontrol yang lain, memori yang lebih besar, pin input dan output yang lebih banyak dibanding mikrokontroler yang lain[8][9]. 


\section{Metode penelitian}

Diagram Block Sistem Pengendali Kecepatan Limestone Weight Feeder

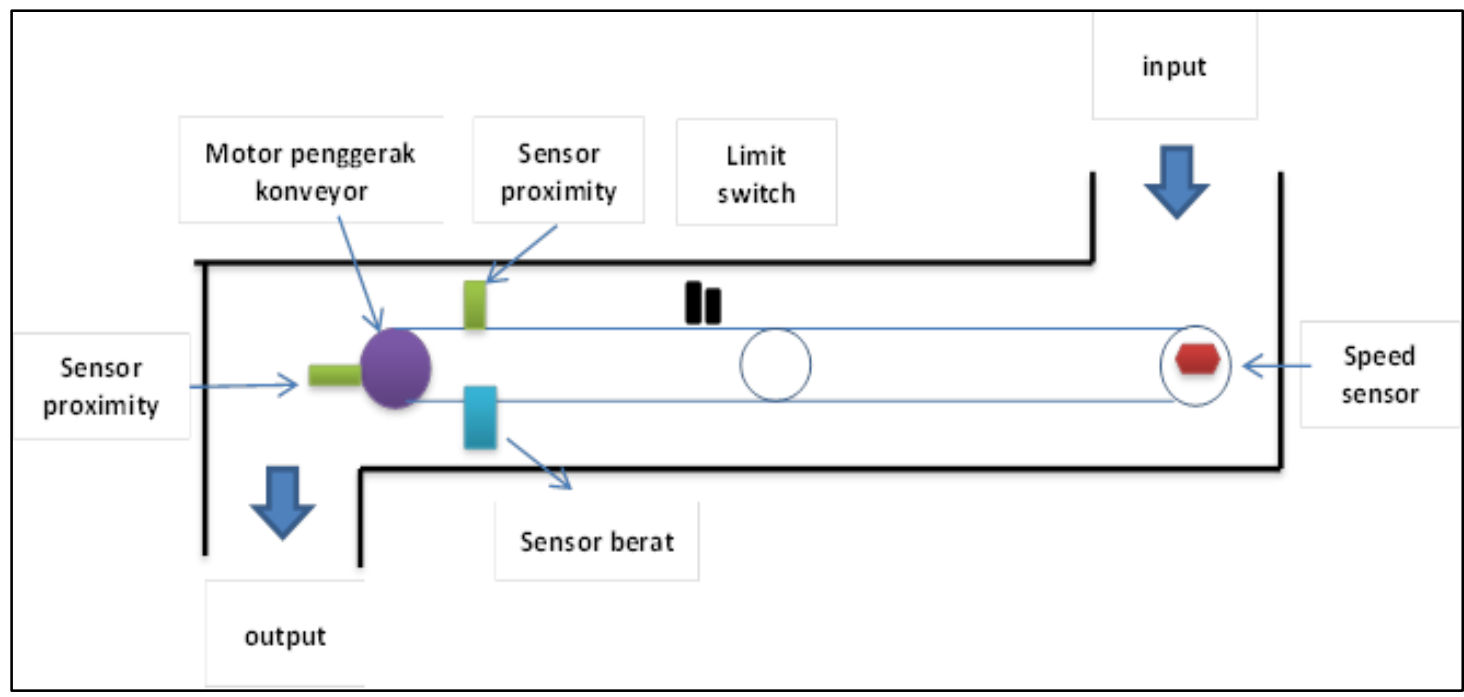

Gambar 2.1 Blok Diagram Sistem

Prinsip kerja dari sistem di atas sebagai berikut Operator memberikan nilai set point berat limestone yang digunakan dalam proses FGD pada Arduino Mega 2560. Arduino Mega memberikan sinyal pada Motor DC untuk menggerakkan conveyor. Sinyal Arduino Mega 2560 juga terbaca oleh sensor kecepatan dan load cell berupa berat limestone yang harus terpenuhi dalam satuan jam. Jika berat limestone yang terbaca oleh load cell belum sesuai dengan set point, maka sensor kecepatan akan menambah kecepatan konveyor[10][11]. Pada sistem ini terdapat dua proteksi untuk yang dapat mematikan konveyor.

1. Limit Switch untuk belt misalignment 2 pcs (kiri dan kanan).

2. Limit Switch proteksi ketika terjadi penyumbatan material batu kapur pada outlet Limestone Weight Feeder

\section{Flue Gas Desulphurization (FGD)}

Penggunaan batubara sebagai bahan bakar utama pada boiler menghasilkan dua produk utama yaitu bottom ash dan fly ash. Bottom ash akan langsung turun ke bagian bawah boiler ditampung oleh primary ash silo, sedangkan fly ash yang merupakan abu yang ringan sehingga ikut terbawa ke dalam aliran gas (flue gas) yang dialirkan melalui stack dan ini sangat berbahaya bagi lingkungan sehingga dipasang ESP (Electro Static Precipitator). ESP adalah alat yang digunakan untuk menangkap debu fly ash dengan menggunakan prinsip electrostatic.Selain limbah padat yang terkandung pada fly ash juga terdapat limbah kimia berupa SOx dan NOx yang tidak dapat dieliminir oleh ESP untuk itu perlu dipasang Flue Gas Desulphurization (FGD)[12].FGD adalah alat yang berguna untuk menghilangkan/mereduksi $\mathrm{SO}_{2}$.Pada PLTU Tanjung Jati B Unit \#3\&4 sistem FGD yang digunakan adalah tipe kering (dry FGD) yaitu dengan memasukkan udara flue gas ke dalam system dan disemprot dengan menggunakan zat kimia absorber sulfur berupa $\mathrm{CaCO}_{3}$ (limestone) sehingga menghasilkan reaksi kimia: $\mathrm{CaCO}_{3}($ solid $)+\mathrm{SO}_{2}$ (gas) $\rightarrow \mathrm{CaSO}_{3}$ (solid) $+\mathrm{CO}_{2}$ (gas)

Pada FGD tipe dry, berat limestone yang digunakan harus sesuai dengan jumlah gas $\mathrm{SO}_{2}$ yang akan direduksi. Pengaturan berat limestone ini harus otomatis dan real dapat dilihat langsung oleh operator[13].

Programmable Logic Controller (PLC).

PLC adalah piranti elektronika digital yang menggunakan memori yang bisa diprogram sebagai penyimpan internal dari sekumpulan instruksi dengan mengimplementasikan fungsifungsi tertentu, seperti logika, sekuensial, pewaktuan, perhitungan, dan aritmatika, untuk mengendalikan berbagai jenis mesin ataupun proses melalui modul $\mathrm{I} / \mathrm{O}$ digital dan atau analog. 


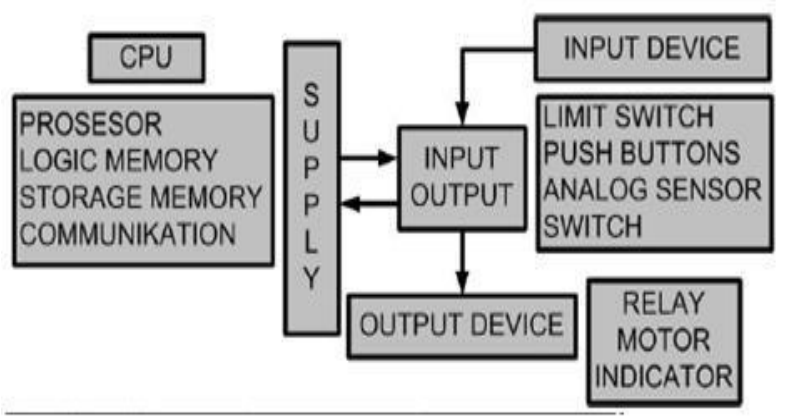

Gambar 1 Blok Diagram PLC

PLC yang digunakan dalam penelitian ini adalah PLC OMRON tipe ZEN-10C1AR-A-V1 yang memiliki $10 \mathrm{I} / \mathrm{O}$ (6 inputs dan 4 outputs) dengan sumber tegangan $220 \mathrm{VAC}$ dan sumber tegangan output 12 VDC. Bahasa pemrograman yang digunakan adalah diagram tangga[14]. Pada PLC OMRON tipe ZEN-10C1AR-A-V1 terdapat dua macam pewaktu, yaitu

- Pewaktu (Timer): Nilai pewaktu saat ini akan di-reset saat pewaktu diubah dari mode RUN ke mode STOP atau catu daya PLC dimatikan. Terdapat empat macam operasional pewaktu jenis ini, yaitu tundaan ON,tundaan OFF, pulsa tunggal dan pulsa kedip.

- Pewaktu tahan: Nilai pewaktu saat ini akan disimpan walaupun terjadi pengubahan mode RUN menjadi STOP atau catu daya dimatikan. Pewaktuan akan dilanjutkan kembali jika masukan pemicu ON, selain itu status ON pada bit pewaktu tahan ini akan disimpan jika waktu yang dikehendaki sudah selesai. Bit pewaktu tahan ini hanya bisa beroperasi dengan fungsi tundaan ON saja.

PLC tipe ini juga dilengkapi dengan Pencacah (Counter) dimana terdapat 16 pencacah yang dapat digunakan dalam mode naik (increment) maupun turun (decrement). Nilai saat ini dari pencacah akan disimpan jika mode operasi PLC diubah atau catu daya dimatikan. Bit pencacah akan ON jika nilai cacah sudah melampaui yang ditentukan. Nilai pencacah kembali ke 0 (nol) jika di-reset. Jenis-jenis counter antara lain: 1) Counter up: yaitu counter yang melakukan pencacahan naik (incremental); 2) Counter down: melakukan pencacahan secara menurun (decremental); 3) Counter set: counter yang setelah aktif maka akan memerintahkan set operasi; 4) Counter reset: counter yang melakukan operasi reset[15].

Weight Feeder Conveyor.

Pinsip kerja weight feeder conveyor adalah sebagai berikut: material atau bahan yang lewat pada belt conveyor akan dideteksi oleh load cell (sensor berat). Pengendali berfungsi untuk memberikan nilai pembanding yang berasal dari pembacaan data. Inputan untuk sistem ini adalah sinyal dari load cell dan speed sensor (rotary encoder) berupa kecepatan konveyor. Kemudian kedua masukan ini dikalikan di controller menghasilkan sinyal federate dengan formula sebagai berikut:

$$
\text { feedrate }=\text { berat } \times \text { kecepatan }
$$

Sistem pengaturan jumlah komponen bahan atau material dilakukan dengan mengurangi atau menambah kecepatan pada motor driver belt conveyor.

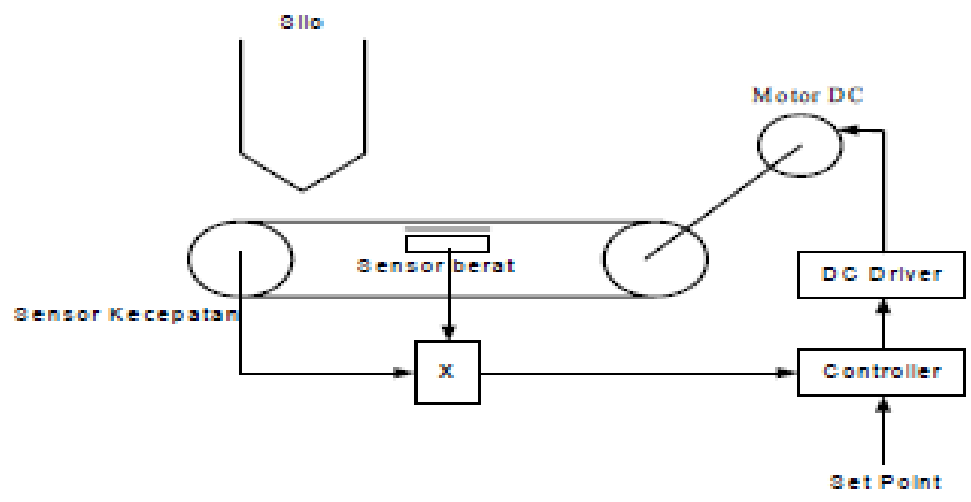

Gambar 2 Sistem Loop Tertutup pada Weight Feeder 


\section{Arduino Mega 2560}

Arduino Mega 2560 adalah sebuah board mikrokontroller yang berbasis Arduino dengan menggunakan chip ATmega 2560. Board ini memiliki 54 pin I/O (15 pin dintaranya PWM), 16 pin analog inpun, 4 pin UART (serial port hardware). Arduino Mega 2560 dilengkapi dengan sebuah oscillator $16 \mathrm{Mhz}$, sebuah port USB, power jack DC, ICSP header, dan tombol reset.

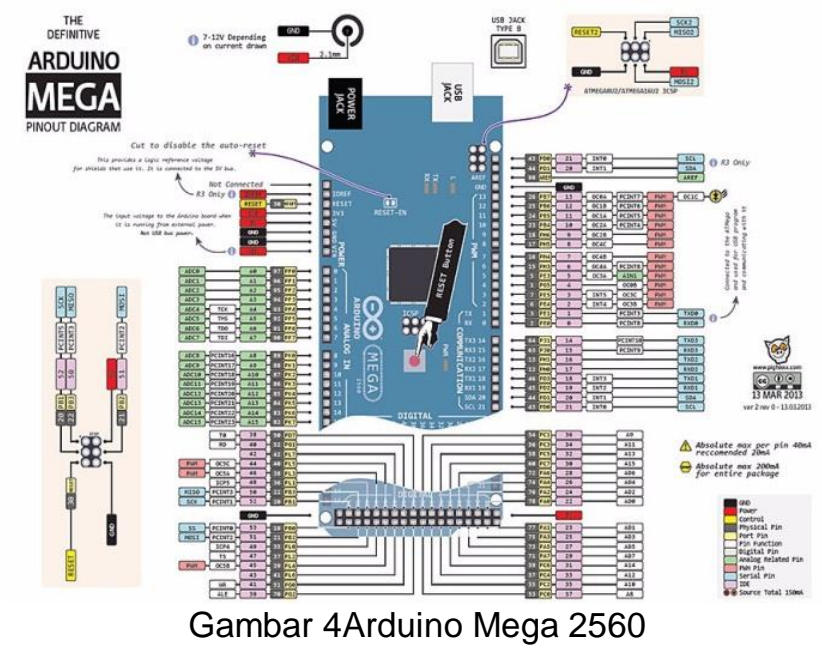

\section{Hasil dan Analisis}

\subsection{Pengujian Pembacaan Sensor dan Load Cell}

Pengujian bertujuan untuk menentukan tingkat keakurasian pembacaan sensor terhadap berat benda serta presentase nilai kesalahan (error) yang yang terjadi pada alat timbangan digital. Berikut hasil pembacaan sensor load cell pada timbangan digital penentu

\begin{tabular}{|c|c|c|c|c|c|c|c|}
\hline \multirow{2}{*}{$\begin{array}{c}\text { Berat } \\
\text { Sesungguhnya } \\
\text { X (gram) }\end{array}$} & \multicolumn{5}{|c|}{$\begin{array}{l}\text { Hasil Pengukuran alat timbangan } \\
\qquad \text { (gram) }\end{array}$} & \multirow{2}{*}{$\begin{array}{c}\text { Rata-rata } \\
\text { kesalahan } \\
\text { S (gram) }\end{array}$} & \multirow{2}{*}{$\begin{array}{c}\text { STingkat } \\
\text { kesalahan } \\
\text { E(Error) }\end{array}$} \\
\hline & $\mathrm{y} 1$ & y2 & y3 & y4 & y5 & & \\
\hline 0 & 0 & 0 & 0 & 0 & 0 & 0 & 0 \\
\hline 50 & 49 & 49 & 49 & 49 & 49 & 1 & 2 \\
\hline 100 & 101 & 101 & 101 & 101 & 101 & -1 & -1 \\
\hline 200 & 200 & 200 & 200 & 200 & 200 & 0 & 0 \\
\hline 250 & 249 & 249 & 249 & 249 & 249 & 1 & 0.4 \\
\hline 500 & 499 & 499 & 499 & 499 & 499 & 1 & 0.2 \\
\hline 1000 & 1002 & 1002 & 1002 & 1002 & 1002 & -2 & -0.2 \\
\hline 1500 & 1502 & 1504 & 1502 & 1504 & 1502 & -2.8 & -0.18666667 \\
\hline 2000 & 2001 & 2001 & 2002 & 2002 & 2002 & -1.6 & -0.08 \\
\hline 3000 & 3003 & 3003 & 3003 & 3002 & 3002 & -2.6 & -0.08666667 \\
\hline 4000 & 4005 & 4005 & 4005 & 4005 & 4005 & -5 & -0.125 \\
\hline 5000 & 5006 & 5006 & 5006 & 5006 & 5006 & -6 & -0.12 \\
\hline \multicolumn{7}{|c|}{ Rata-rata tingkat kesalahan } & 0.809 \\
\hline
\end{tabular}

Tabel 1. Hasil Pembacaan Sensor Load Cell

Berikut cara menghitung rata - rata presentase tingkat kesalahan:

$$
\Sigma E=\bar{E} / X=0.809 / 12=0.067 \%
$$




\section{Pengujian Sensor Proximity}

Langkah pengujian sensor proximity melewati beberapa tahapan, yaitu:

- Menghubungkan catu daya 24 volt DC ke bagian driven sensor

- Melakukan pengujian bagian sensor yang diinginkan untuk mendapatkan hasil yang diinginkan dengan menggunakan multimeter digital untuk melihat apakah keluarab dari sensor tersebut benar atau tidak

- Mencatat hasil pengujian

\begin{tabular}{|c|c|c|l|}
\hline No & $\begin{array}{c}\text { Sensor } \\
\text { Proximity }\end{array}$ & $\begin{array}{c}\text { Hasil } \\
\text { Pengujian }\end{array}$ & \multicolumn{1}{|c|}{ Keterangan } \\
\hline \multirow{2}{*}{1} & \multirow{2}{*}{ Sensor 1 } & 0 & Konveyor 1 dalam keadaan stop \\
\cline { 3 - 4 } & & 1 & Konveyor 1 dalam keadaan berputar \\
\hline \multirow{2}{*}{2} & \multirow{2}{*}{ Sensor 2 } & 0 & Konveyor 2 dalam keadaan stop \\
\cline { 3 - 4 } & & 1 & Konveyor 2 dalam keadaan berputar \\
\hline
\end{tabular}

Tabel 2. Hasil Pengujian Sensor Proximity

- Uji pendekatan pertama dilakukan oleh satu telapak tagab yang endekati proximity sensor dengan jarak sekotar $2 \mathrm{~cm}$ dari proximity sensor dan frekuensi yang dihasilkan $27.210 \mathrm{~Hz}$

- Pada pendekatan yang kedua dilakukan dengan telapak tangan pada jarak yang sama didapatkan frekuensi $26.540 \mathrm{~Hz}$

- Uji proximity sensor, didekati dengan objek yang memiliki dielektrik yang berbeda tetapi dengan jarak ke proximity sensor dan luas penampang yang sama

Gambar di bawah ini adalah sinyal pulsa motor PWM dimana teangan 12 volt dan RPM 1500 diinjeksikan pada kaki EN12 dan akan mengatur kecepatan motor

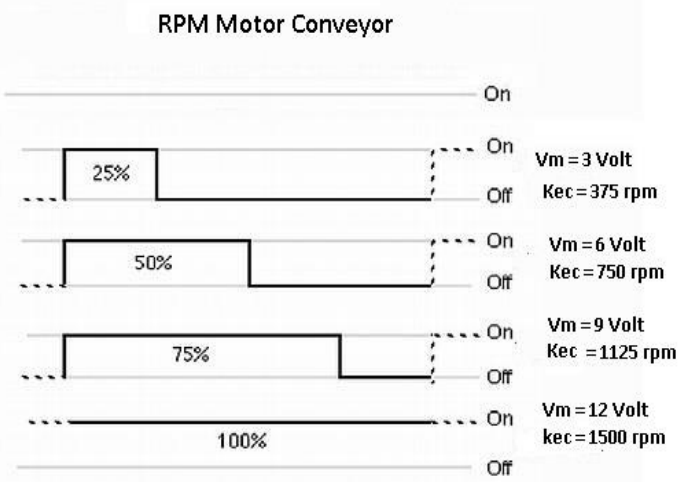

Gambar 7Sinyal PWM

\section{Pengujian Arduino Mega 2560}

Pengujian pada Arduino Mega 2560 dapat dilakukan dengan mengupload program ke Arduino Mega 2560. Setelah program terupload dengan baik, Led 13 akan merespon dengan baik status nyala dan padam sesuai dengan perintah

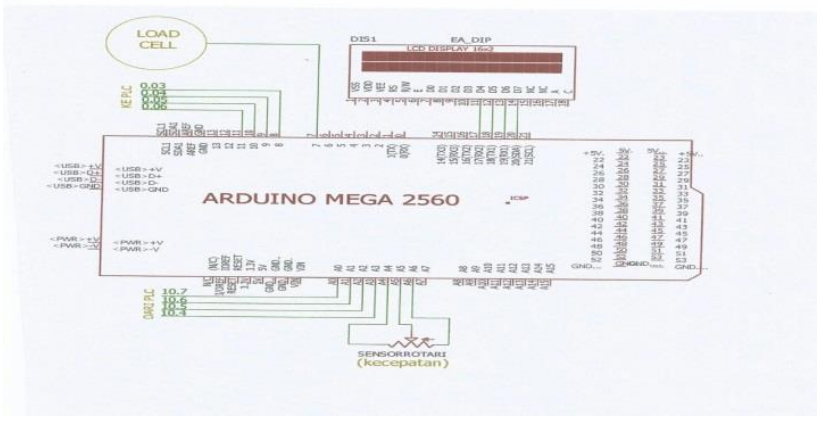




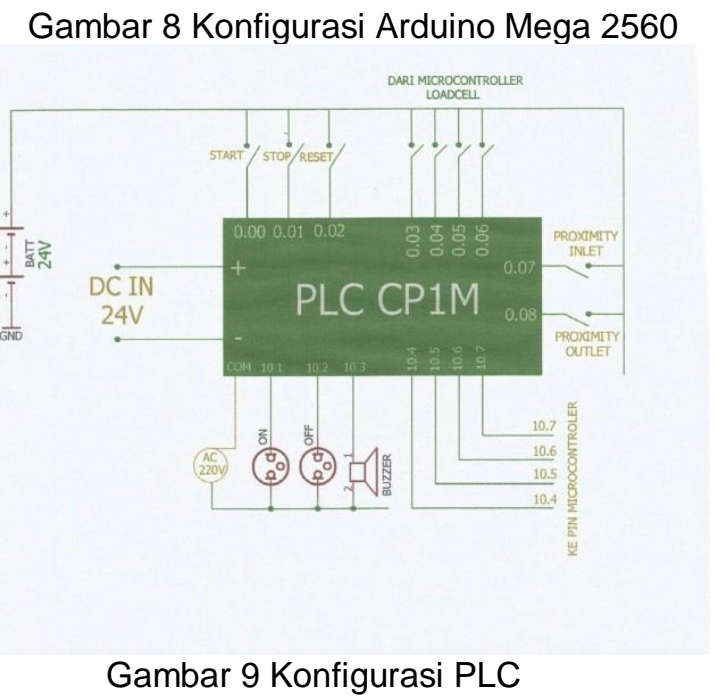

\section{Kesimpulan}

Kesimpulan perancangan Mini Plant Sistem Pengendali Limestone pada PLTU Tanjung Jati B Unit \#3 dan 4 lebih sederhana daripada sistem pengendali weight feeder dengan menggunakan PID dan Fuzzy dimana proses penghitungan berat limestone menggunakan PLC dan Arduino Mega 2560. Sistem pengontrolan Limestone Weight Feeder pada FGD berbasis Arduino Mega 2560 memiliki nilai rata - rata tingkat kesalahan sebesar $0.067 \%$. Sistem Kontrol Limestone Weight Feeder dengan berbasis PLC dan Arduino Mega 2560 lebih aplikatif dibanding sistem kontrol menggunakan PID dan Fuzzy. Mini Plant untuk Sistem Kontrol Limestone Weight Feeder pada FGD dapat disempurnakan untuk penelitian lebih lanjut.

\section{Pengakuan dan Penghargaan}

Terima Kasih kepada Program Studi Teknnik Elektro Fakultas Teknik Universitas Merdeka Malang atas dukungan sarana dan prasara sehingga penulis bisa menelesaikan penelitian dengan tujuan akhir sebagai hasil Tugas Akhir dari studi.

Penelitian ini didukung oleh Laboratorium Teknik Elektro Universitas Merdeka Malang

\section{References}

[1] J. A. de L. Perini et al., "Optimisation of the removal conditions for heavy metals from water: A comparison between steel furnace slag and CeO2nanoparticles," Arab. J. Chem., 2017.

[2] I. Hrastel, M. Gerbec, and A. Stergaršek, "Technology optimization of wet flue gas desulfurization process," Chem. Eng. Technol., 2007.

[3] R. Jamil, L. Ming, I. Jamil, and R. Jamil, "Application and Development Trend of Flue Gas Desulfurization (FGD) Process: A Review," Int. J. Innov. Appl. Stud. ISSN, 2013.

[4] Handy Wicaksono and Josaphat Pramudijanto, "Kontrol PID Untuk Pengaturan Kecepatan Motor DC Dengan Metode Tuning Direct Synthesis," J. Tek. Elektro, 2004.

[5] I. Mujahidin, R. Yuwono, and A. Mustofa, "Rancang Bangun Rectifier Antenna Mikrostrip Ufo Pada Frekuensi Ultra Wideband (UWB) Sebagai Pemanen Energi Elektromagnetik," J. Mhs. TEUB, vol. 3, no. 2, 2015.

[6] W. Bolton, "PLC systems," in Instrumentation and Control Systems, 2007.

[7] X. Zhang, X. Li, and K. Lu, "Research on an intelligent solar tracking system based on LPC2131," in Proceedings - 2012 3rd IEEE International Conference on Network Infrastructure and Digital Content, IC-NIDC 2012, 2012.

[8] M. A. R. Arif Rahman Hakim, Sumardi, "Kontrol Posisi Pada Sistem Pergerakan Mobile Robot Kinematic," Article, 2015.

[9] I. Mujahidin, "Directional 1900 Mhz Square Patch Ring Slot Microstrip Antenna For WCDMA," JEEMECS (Journal Electr. Eng. Mechatron. Comput. Sci., 2019.

[10] G. P. H. Sandaruwan, P. S. Ranaweera, and V. A. Oleshchuk, "PLC security and critical infrastructure protection," in 2013 IEEE 8th International Conference on Industrial and

Mini Plant Sistem Pengendali Berat Limestone Pada Pltu Tanjung Jati B Unit \#3\&4 Berbasis PlC Danarduino Mega 2560 (Surya N Santika) 
Information Systems, ICIIS 2013 - Conference Proceedings, 2013.

[11] I. Mujahidin, S. H. Pramono, and A. Muslim, "5.5 Ghz Directional Antenna with 90 Degree Phase Difference Output," 2019.

[12] L. E. Kallinikos, E. I. Farsari, D. N. Spartinos, and N. G. Papayannakos, "Simulation of the operation of an industrial wet flue gas desulfurization system," Fuel Process. Technol., 2010.

[13] F. M. W. Fatih Mutamimul Wildan, "Sistem Pengaturan Kecepatan Motor Induksi Tiga Fasa Menggunakan Kontroler PID Berbasis Genetic Algorithm," KINETIK, 2016.

[14] J. T. Elektro, F. T. Industri, and U. K. Petra, "Kontrol PID Untuk Pengaturan Kecepatan Motor DC Dengan Metode Tuning Direct Synthesis," vol. 4, no. 1, pp. 10-17, 2004.

[15] L. P. Ketaren, M. Ma, and M. Rahmawaty, "Balancing Robot Beroda Dua Menggunakan Metoda Kontrol Proporsional , Integral dan Derivatif," J. Elem., 2015.

\section{Daftar Riwayat Hidup}

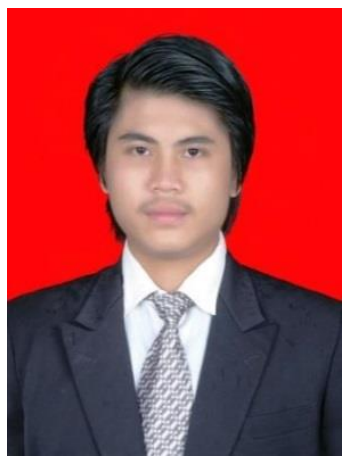

Surya Nanda Santika, lahir di Banjarmasin 16 September 1987, agama Islam. Penulis menamatkan pendidikan SD tahun 1993 di SDN 02 Panggung Rejo 2lulus tahun 1999. Setelah itu penulis melanjutkan pendidikan SMP tahun 1999 di SMPN 1 Kauman lulus tahun 2002, pendidikan SMA tahun 2002 di SMAN 01 Kedungwaru lulus pada tahun 2005, pendidikan D3 tahun 2005 di Politeknik Elektronika Negeri Surabaya $t$ bahan bakar berbas(PENS-ITS) pada jurusan Elektronika Industri lulus pada tahun 2008. Dan melanjutkan pendidikan S1 pada jurusan Teknik Elektro Universitas Merdeka Malang hingga saat ini 